\title{
The Study of Inflation Rate and Relative Impact on the Indian Economy during Covid-19 Pandemic
}

\author{
Dr. S.K.S. Yadav ${ }^{1}$, Arushi Jain ${ }^{2}$, Shilpa Narang ${ }^{3}$ \\ ${ }^{1}$ Associate Professor Faculty of commerce and Business Administration Meerut College, C.C.S. University, U.P., India \\ ${ }^{2}$ Research Scholar, C.C.S. University, Meerut, U.P., India \\ ${ }^{3}$ Assistant Professor, Institute of Innovation in Technology and Management \\ Affiliated to Guru Gobind Singh Indraprastha University, Delhi, India
}

\begin{abstract}
COVID-19 has affected the entire world. India, like other countries have adopted the safest way of lockdown in order to prevent the pandemic. One of the most critical impact of lockdown is increasing inflation. Covid-19 has affected the economy in many ways, but the most tangible outcome is the impact of inflation that has affected each and every person. Even into the pandemic, Inflation in India did not see it going below 6\%. Inflation has been one of the most burning issue of economics. It is an increase in the prices of daily commodities over a period. This paper is an attempt to understand the impact of inflation on Indian economy during COVID-19. The paper looks at the methods that are used to measure the level of inflation, and the factors that are responsible for the current high level of inflation in India during COVID-19.
\end{abstract}

KEYWORDS: Covid 19, Inflation, Indian economy, Pandemic

\section{INTRODUCTION}

Growth and stability are the two sides of the same coin. Uncertainty never leads to the economic development of the country. Fluctuation in the prices is not a good indicator for the development of the country. Inflation is an unpredictable phenomenon and is present in every economy. It is necessary to control the level of inflation to balance the growth and development of the economy. 2020, with the global COVID-19 pandemic, Inflation is slowly biting the Indian economy. On the one hand, there was a decline in demand due to a drop-in economic activity. On the other hand, disruptions in the supply chain have caused drastic changes in the rate of food price inflation, which persist over the life of the economy.

Inflation is one of the biggest challenges for the economy, and India's economy, which is on the path of growth and development, the inflation is slowly disturbing the economy .In this research paper, we will continue to analyse the factors and challenges that inflation will bring, and provide a brief description of its activities at the time of COVID-19. Inflation is an increase in the overall level of prices for goods and services in the economy in a given time period. Inflation means paying more for goods than paying earlier. The price of everything goes up over time and this phenomenon is referred as inflation. Due to increase in the overall price, each unit of currency buys fewer goods and services. As a result, inflation reflects a decrease in the purchasing power of a unit of money-a loss of real value in terms of exchange and currency in the economy.

The level of inflation is defined as a steady increase in the overall level of prices for goods and services. In India, inflation is measured as the percentage change in the Wholesale Price Index (WPI) of a basket of goods and services in annual terms. According to the Economic Times, the inflation rate is the percentage change in the value of the wholesale price index (CPI) in annual terms. It reflects changes in the prices of a basket of goods and services during the year. The Consumer Price Index (CPI) is used to measure the rate of Inflation in India

\section{LITERATURE REVIEW}

Literature is an important part of the early investigation. This will give scientists the opportunity to conduct further research, as well as the discovery of the hidden and unfamiliar areas of study.

Friedman, in his study found that presence of inflation is a monetary phenomenon. His theory argued that if the supply of money increases faster than the growth rate of national income then inflation is bound to occur and there will be no inflation if money supply and inflation increases with an equal rate. Thornton (2006) used the GARCH model and stated that there is a direct and significant relationship between the level and variability of monthly uncertainty in various emerging markets including India. 


\title{
International Journal of Current Science Research and Review
}

ISSN: 2581-8341

\author{
Volume 04 Issue 08 August 2021
}

DOI: 10.47191/ijcsrr/V4-i8-03, Impact Factor: 5.825

IJCSRR@ 2021

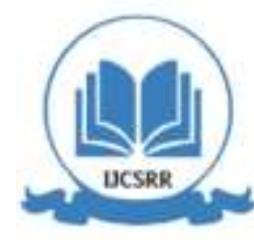

www.ijcsrr.org

Khundrakpam and Goyal (2009) in their study founded that the rise in inflation is caused due to unfavourable supply shocks which may not merit monetary tightening as long as the permanent changes in relative energy price do not lead to the changes in the rate of inflation.Lokeswar Reddy, (2012) through his paper "Impact of Inflation and GDP on Stock Market Returns in India" emphasized that Inflation is a situation in the economy where, there is more money chasing less of goods and services. Osmerod et al. (2013) through his study provided crucial conclusions about both inflation and unemployment dynamics in the context of advanced economies, such as the UK, the US and Germany.Abdhur chawdhary (2014) founded that the Inflation and its related uncertainty can impose costs on real economic output in any economy According to (Forbes, 2014) the country with the highest rate of inflation is Venezuela, with the current inflation rate of $57.30 \%$. There are different types of inflation which are cost-push and demand-pull inflation Naresh Kanwar (2014) founded that the food price inflation has been of the persistent problem over the past years (Investor Words, 2015) stated that the surplus supply of money caused an increase in the general price level of goods and services. Consumer Price Index is used to measure inflation. When the cost of producing goods and services increases, the purchasing power of dollar will decrease. Tariq Zafar(2016) through his study founded that the inflation from one side increases the general cost and from the other side it reduces the savings Dr.S.Jamuna, (2016) through his study "Inflation and its impact on India" founded that the Inflation is a major public concern and always been subject to heated political debate, Behera et al. (2017) through his study revealed that their is an inverse relationship for both core and headline inflation, with the effect of excess demand being more significant in core inflation.Andre Roncaglia (2017) studied the relation between economic development and level of inflation and found a statistically significant inverse correlation between them. They collected data for 65 countries between 2001 and 2011 and showed that the inflation levels are affected by development-related factors. Daya Mary Mathew, S. Ancy, J.Aruna Jasmine(2020) through their study has founded that Covid-19 has brought several industries to standstill and brought substantial trade deficit for India.

\section{EXPLORING THE RESEARCH GAP}

It is evident rom the Literature review of the research issue that even after taking several measures problem of high inflation is still prevalent in the country. That is why, there is still a need to study the various other factors for high inflation rates during pandemic.

\section{OBJECTIVE OF THE STUDY}

1.To assess the impact of the inflation rate on the Indian economy caused by COVID-19.

2. To analyse the qualitative, quantitative, and collective impact on various sectors of the economy due to rising inflation.

3.To suggest various measures to reduce the impact of the inflation rate.

\section{RESEARCH METHODOLOGY}

The study is done to analyse the impact of inflation on Indian economy in general and for the purpose secondary data and reports are used which are collected from various published reports, magazines, RBI annual report, research articles and financial and websites. After the judicious evaluation of inflation various suggestions and recommendation are made.

Figure-1. Pre Covid-Inflation Rates

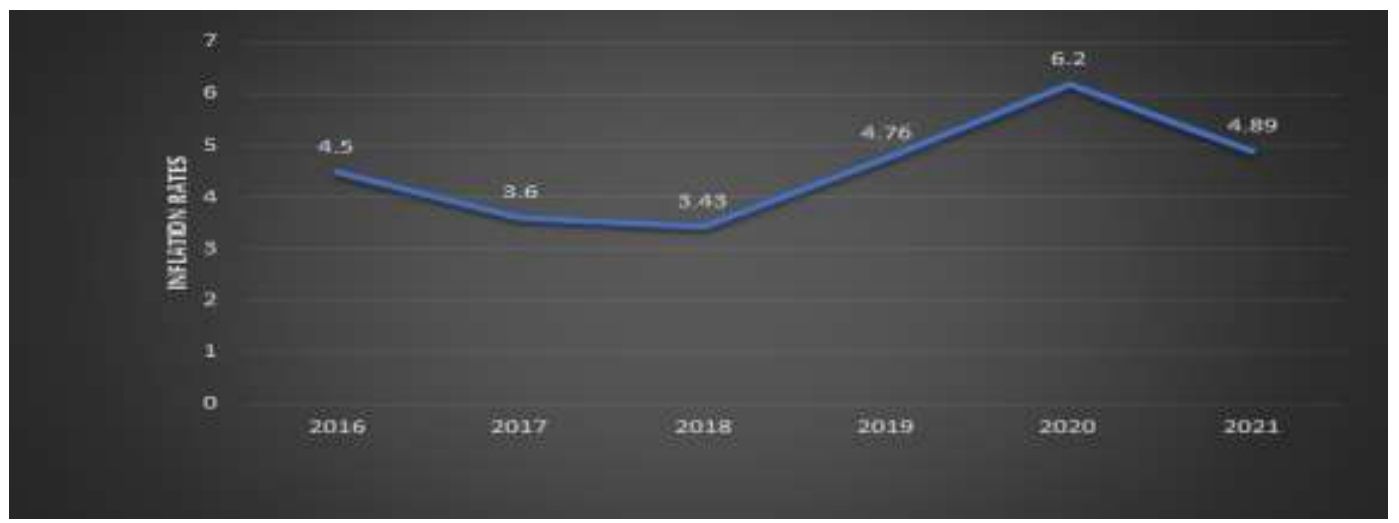

Source: Statista 2021 annual survey. 


\section{International Journal of Current Science Research and Review}

ISSN: 2581-8341

Volume 04 Issue 08 August 2021

DOI: 10.47191/ijcsrr/V4-i8-03, Impact Factor: 5.825

It is clearly depicted from the above chart that the inflation rate has been continuously increasing from the year 2018 and is the highest in the year $2020(6.2 \%)$ due to pandemic.

\section{Inflation in India during 2020 (CPI)}

The chart and table below depicts an overall view of the Indian inflation in 2020: CPI India 2020. The rates of inflation are based upon the consumer price index (CPI). In the table below, the CPI inflation rates are presented both on the monthly basis (compared to the month before) as well as on a yearly basis (compared to the same month the year before).

Figure-2. CPI inflation in India -2020 (yearly basis)

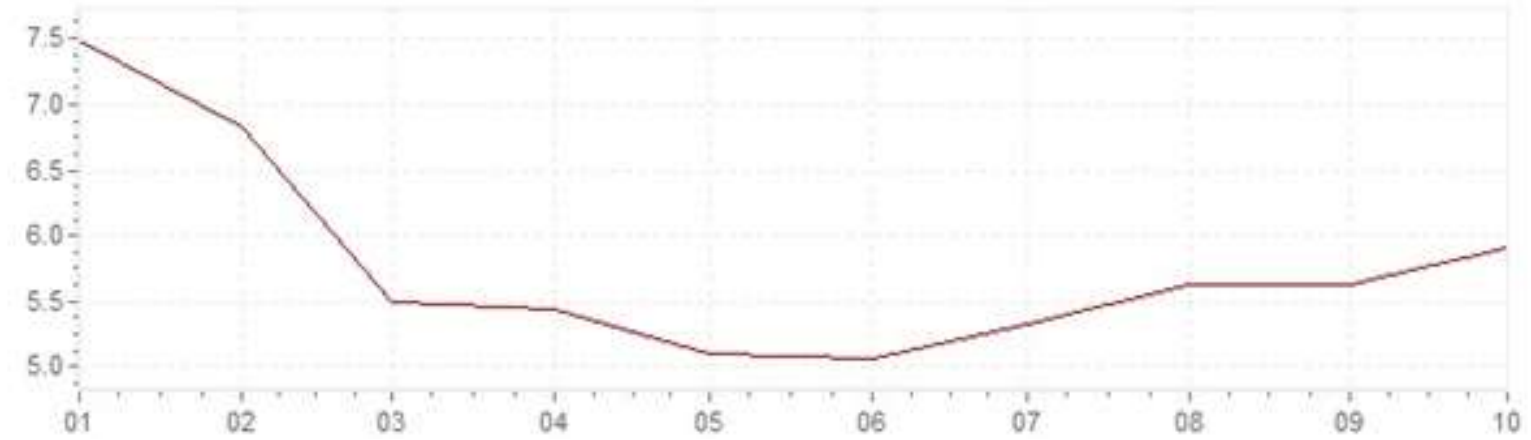

The average inflation of India in 2020: $\mathbf{5 . 5 8} \%$

Source: Inflation.eu India-2020

Table - 1. CPI inflation in India -2020 ( monthly and yearly basis)

\begin{tabular}{|l|lll|}
\hline & inflation & inflation (yearly basis) & inflation \\
\hline January 2020 - December 2019 & $0.00 \%$ & January 2020 - January 2019 & $7.49 \%$ \\
\hline February 2020 - January 2020 & $-0.61 \%$ & February 2020 - February 2019 & $6.84 \%$ \\
\hline March 2020 - February 2020 & $-0.61 \%$ & March 2020 - March 2019 & $5.50 \%$ \\
\hline April 2020 - March 2020 & $0.92 \%$ & April 2020 - April 2019 & $5.45 \%$ \\
May 2020 - April 2020 & $0.30 \%$ & May 2020 - May 2019 & $5.10 \%$ \\
June 2020 - May 2020 & $0.61 \%$ & June 2020 - June 2019 & $5.06 \%$ \\
\hline July 2020 - June 2020 & $1.20 \%$ & July 2020 - July 2019 & $5.33 \%$ \\
august 2020 - July 2020 & $0.60 \%$ & August 2020 - August 2019 & $5.63 \%$ \\
September 2020 - august 2020 & $0.64 \%$ & September 2020 - September $20195.64 \%$ \\
\hline October 2020 - September 2020 & $1.19 \%$ & October 2020 - October 2019 & $5.90 \%$ \\
\hline November 2020 - October 2020 & $0.33 \%$ & November 2020 - November $20195.28 \%$ \\
\hline December 2020 - November 2020 & $-0.92 \%$ & December 2020 - December 2019 & $3.69 \%$ \\
\hline
\end{tabular}

Source: Inflation.eu India (2020) 


\section{International Journal of Current Science Research and Review}

ISSN: 2581-8341

Volume 04 Issue 08 August 2021

DOI: 10.47191/ijcsrr/V4-i8-03, Impact Factor: 5.825

IJCSRR @ 2021

www.ijcsrr.org

Figure-3. The rate of inflation during pandemic

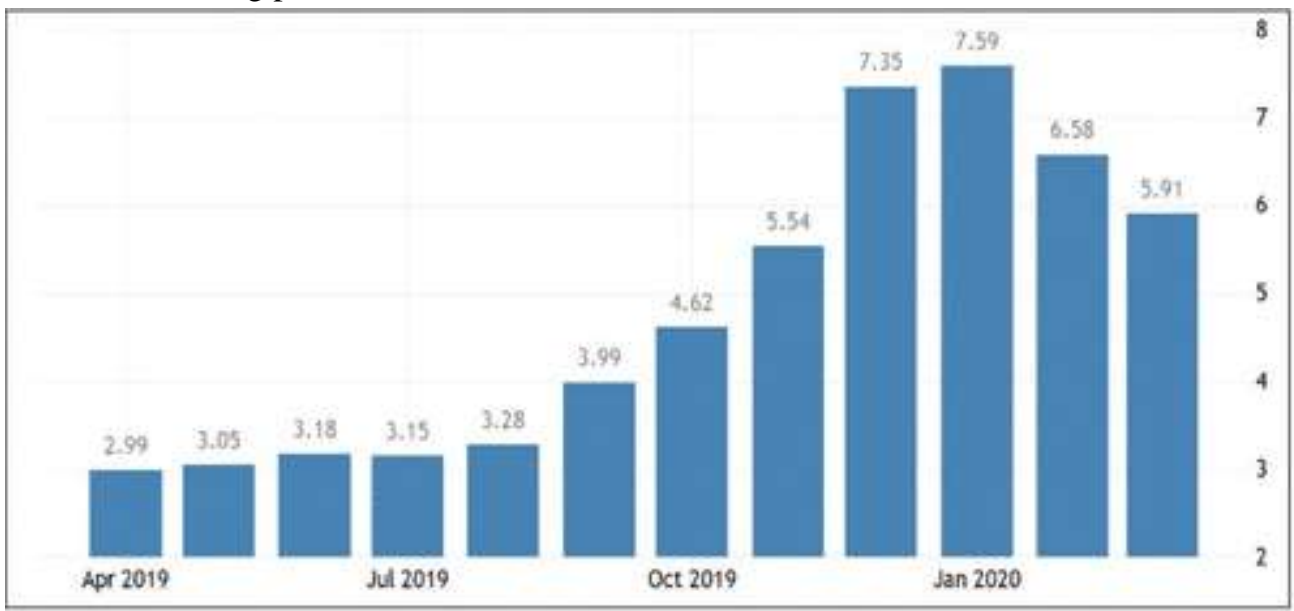

Source: Ministry of statistics and programme implementation

The figure clearly depicts the rising inflation during (2019-2020) and is at its peak in January 2020 with an inflation rate of 7.59\%.

Figure 4. Inflation during covid pandemic

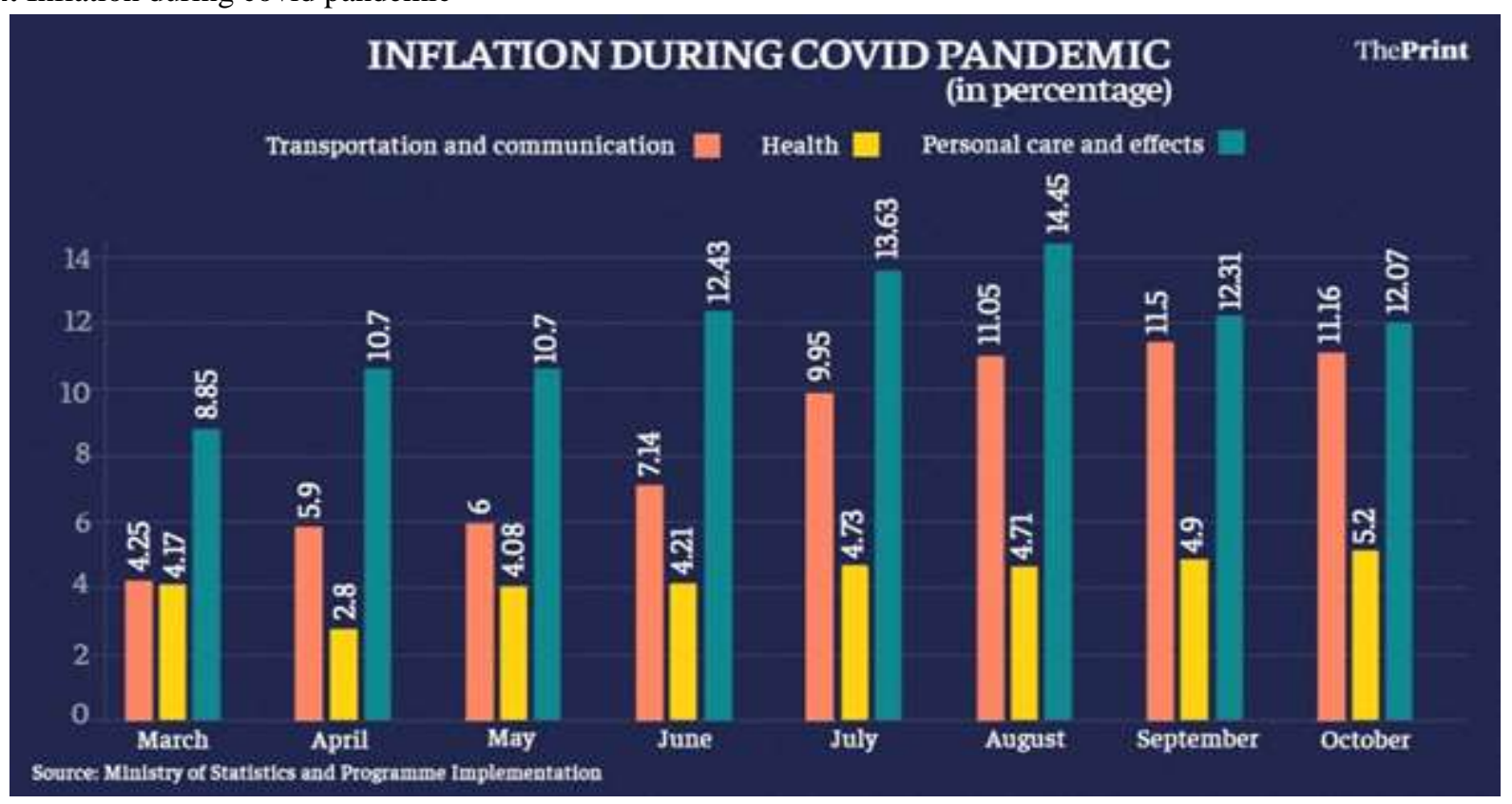

Transportation and communication inflation has been rising continuously and has 8.6 per cent weightage in the overall CPI . The main reason behind this is that the public has started using private transport rather than public transport during pandemic. Personal care has also affected inflation with a rise of 3.9\% due to increase in gold prices. Health inflation has 5.9 per cent weightage in the CPI and has increased from 2.8 per cent in April to 5.2 per cent in October 2020. It has been more than 4 per cent in the last six months. The CPI inflation has increased due to food inflation while the pandemic has also resulted in higher retail inflation. Inflation has remained high for the two commodity groups - health, and transport and communication. In October the food inflation in has increased to 11 per cent from 10.68 per cent in September and has been high over the preceding months due to seasonal and floodinduced shortages. This has increased the retail inflation to over 7 per cent in the last two months. Food and beverages count for more than 45 per cent in the overall retail inflation index. 


\section{International Journal of Current Science Research and Review}

ISSN: 2581-8341

Volume 04 Issue 08 August 2021

DOI: 10.47191/ijcsrr/V4-i8-03, Impact Factor: 5.825

IJCSRR @ 2021

Www.ijcsrr.org

Figure 5. Consumer Price Index Inflation

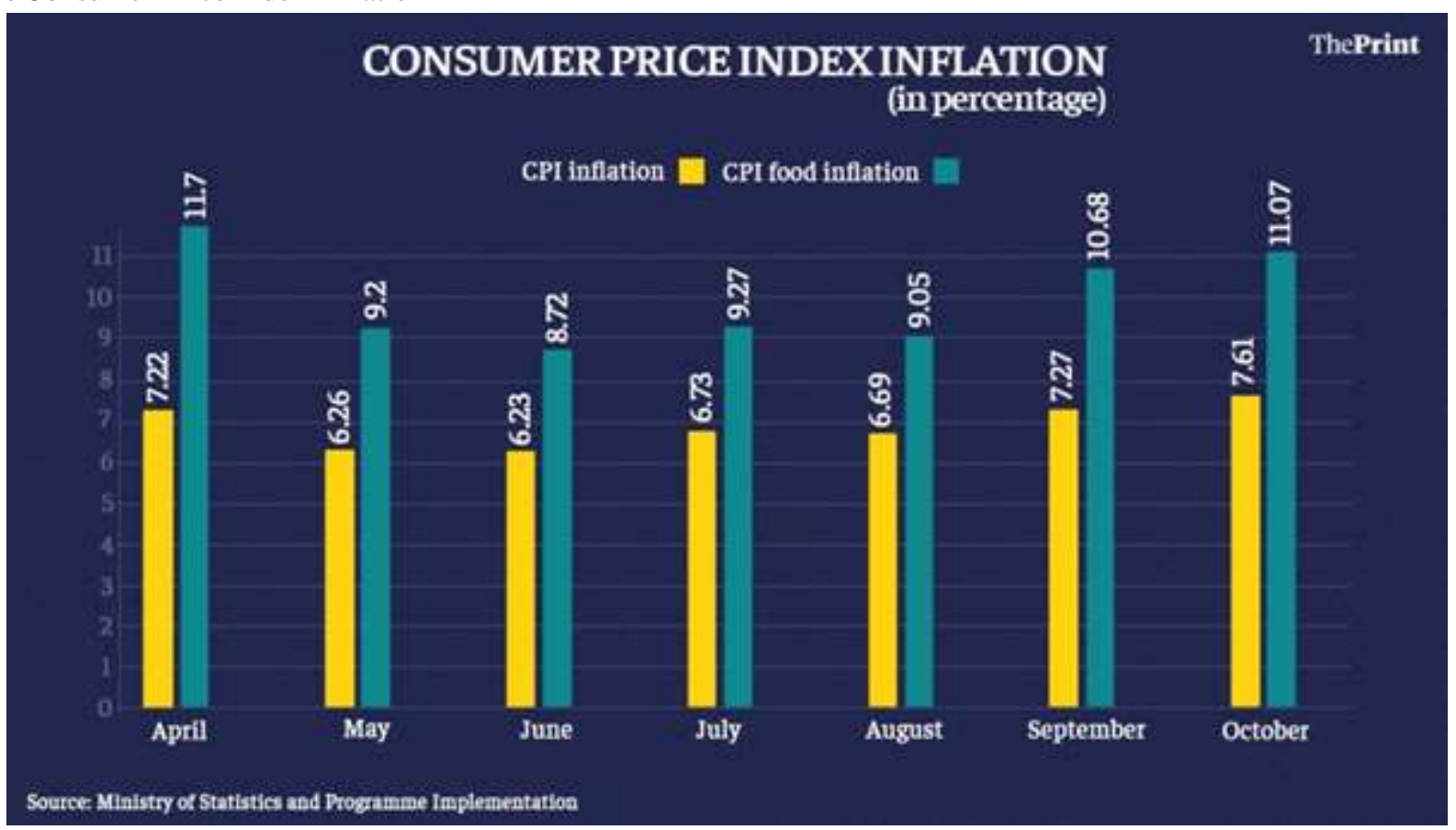

\section{Core Inflation}

The high inflation is not only because of high food inflation. The core inflation, which leaves out food items and fuel and light items, the inflation is at 5.64\%, the highest in two years. An increase in the cost of transportation is the major reason for higher inflation, which went up by $11.16 \%$ in October. Fares of buses, taxies, autorickshaws and rickshaws have gone up and the primarily reason for this is that the petrol and diesel are now more expensive, because the government has increased excise duty on them. The government's dependence on fuel taxes has gone up and that reflects higher inflation. Petrol and diesel used for vehicles come under the transport communication category of the CPI, and not the fuel category.

Another major reason for high core inflation is the rise in inflation in the segments of pan, intoxicants, and tobacco. Interestingly, foreign liquor and beer cost is $22.32 \%$ and $25.32 \%$ more as compared to the last year. The government has increased the taxes in order to increase its revenue.

Inflation in the personal segment is $12.07 \%$ in October. The prices of gold, silver and other ornaments rises significantly by $33.77 \%$, $36.66 \%$ and $20.52 \%$ Inflation in the personal segment is $12.07 \%$ in October. There was a significant rise in the prices of gold, silver and other ornaments, which went up by $33.77 \%, 36.66 \%$ and $20.52 \%$, respectively. Inflation in the health category went up by $5.22 \%$ which is the highest in the year 2019.In October, the price of domestic cooking gas went up by $10.16 \%$, while non-PDS kerosene rises by $8.28 \%$.

\section{CONCLUSION}

The study was carried out on the analysis of the facts and the figures showed that the rate of inflation, and the economy are two sides of the same coin, in the future. Studies have shown that the main cause of inflation is the inflation of food prices, which is in October of $2020,11.07 \%$, core inflation-5.64\%, which was the highest rate in the past 30 years. Inflation is a major influence on the lives of the middle class and the poor class. The control of the rate of inflation is required to be a strong, powerful, and long-term policy of the government. The rate of inflation in general and food inflation, in particular, has been a persistent problem in India over the past few years. The pandemic has caused both demand and supply shock. Due to pandemic both wholesale and retail inflation continued to increase. The major reason behind the inflation rise in India is the sharp rise in the commodity prices. The Government should take protective measures in order to ensure the country's security of supply in order to stimulate the economy and keep the production costs low. The conduct of monetary policy is the main tool for maintaining low inflation rate. Rising interest 


\section{International Journal of Current Science Research and Review}

ISSN: 2581-8341

Volume 04 Issue 08 August 2021

DOI: 10.47191/ijcsrr/V4-i8-03, Impact Factor: 5.825

IJCSRR @ 2021

www.ijcsrr.org

rates, contribute to the reduction of the growth rate of aggregate demand in the economy. The slower growth of aggregate demand will reduce the rate of inflation. The supply policy aimed at the improvement of the long-term competitiveness and productivity. That is why, in the long term, the policy may help to reduce the inflationary pressure. Fiscal policy and demand-side policies are similar, in essence, to make the conduct of monetary policy. To reduce inflationary pressures, the government can increase taxes and decrease government spending.

\section{REFERENCES}

1. Andre Roncaglia (2017), "Economic development and inflation a theoretical and empirical analysis", International review of applied economics 32:4, 546-565

2. Asha Rathi, Ashok Kumar (2020), "Effect of Covid 19 on Various Sectors", International Journal . of Trade and Commerce-IIARTC,Vol.9,No.1, pp.102-110

3. Behera, Harendra, Garima Wahi, and Muneesh Kapur. (2017), Phillips Curve Relationship in India Evidence from StateLevel Analysis. RBI Working Paper Series no.8

4. Chowdhury, A. (2014), "Inflation and inflation-uncertainty in India: the policy implications of the relationship", Journal of Economic Studies, Vol. 41 No. 1, pp. 71-86

5. Das, A. J., and John, and S. Singh (2009), " Measurement of core inflation in India", Indian Economic Review

6. Daya Mary Mathew, S. Ancy, J.Aruna Jasmine (2020), "Effects of covid-19 on the economy", International. Journal of Trade and Commerce-IIARTC, Vol.No.1, pp.27-34

7. DR.S. JAMUNA. (2016, April) "INFLATION AND ITS IMPACT ON INDIAN ECONOMY”, International Journal of Application or Innovation in Engineering \& Management, vol.5.no.4

8. Dr S.M Tariq zafar (2016) “A strategic study on inflation and its relative impact on Indian economy”, International Journal of Core Engineering \& Management vol.3.

9. Khundrakpam J. and R. Goyal (2009), "Is Government Deficit in India still Relevant for Stabilization” Reserve Bank of India Occasional Papers, Vol. 29, No, 3

10. Lokeswar Reddy, D. V. (2012). "IMPACT OF INFLATION AND GDP ON STOCK MARKET RETURNS IN INDIA", International Journal of Advanced Research, vol.1, no.120-136

11. Naresh kanwar, (2014), "Inflation and the Indian Economy", IOSR Journal of Business and Management (IOSR-JBM), vol.16., no. 28-34

12. Osmerod, Paul, Bridget Rosewell, and Peter Phelps. 2013. "Inflation/unemployment regimes and the instability of the Phillips curve". Applied Economics 45: 1519-31

13. Thornton, J., 2006a, "The Relationship Between Inflation and Inflation Uncertainty in Emerging Market Economies" ,Southern Economic Journal Vol. 73, pp. 858-70. V

\section{WEBSITES}

1. (n.d.). Retrieved from Ministry Of Statistics and programme implementation: http://mospi.nic.in/cpi\#

2. (n.d.). Retrieved from statista: https://www.statista.com/statistics/271322/inflation-rate-in-india/

3. (n.d.). Retrieved from Inflation.eu: https://www.inflation.eu/en/inflation-rates/india/historic-inflation/cpi-inflationindia.aspx

Cite this Article: Dr. S.K.S. Yadav, Arushi Jain, Shilpa Narang (2021). The Study of Inflation Rate and Relative Impact on the Indian Economy during Covid-19 Pandemic. International Journal of Current Science Research and Review, 4(8), 853-858 